\title{
Membumikan Teks Agama Ala Nahdlatul Ulama
}

\author{
Muhib Rosyidi ${ }^{1}$
}

\begin{abstract}
This article discusses how Bahtsul Masail Institution in Nahdlatul Ulama uses religious texts - the Qur'ān and Hadith independently from the socio-historical context of Muslim community in Indonesia. The main source of this research is Ahkamul Fuqaha: Solusi Problematika Hukum Islam, Keputusan Muktamar, Munas dan Konbes Nahdlatul Ulama (1926-2004).

The article finds that as the followers of Shäfi'ites, NU's treatment with the text of al-Qur'an and Hadith within local tradition has its own characteristics, in some way differ themselves with the Shäfi ites as a sect. In fact, NU is more likely prefer the local traditions of Muslim society than the religious texts themselves.
\end{abstract}

\begin{abstract}
Abstrak
Tulisan ini mengungkap bagaimana Lembaga Bahtsul Masail Nahdlatul Ulama menggunakan teks agama -al-Quran dan hadisyang independen dengan kondisi sosial historis masyarakat Muslim Indonesia. Bahan utama penelitian ini adalah buku Ahkamul Fuqaha: Solusi Problematika Hukum Islam, Keputusan Muktamar, Munas dan Konbes Nahdlatul Ulama (1926-2004).

Tulisan ini menemukan bahwa sebagai penganut Syafi'i, pergumulan NU dengan teks al-Quran dan Hadis dengan tradisi lokal memiliki ciri tersendiri, bahkan tak jarang berbeda dengan Imam Syafi'i sebagai mazhabnya. Bahkan, warga NU lebih cenderung memilih tradisi lokal masyarkat Muslim dari pada teks agama itu sendiri.
\end{abstract}

Keywords: Bahtsul Masail, tradisi lokal, taqrì jamā‘ $\bar{i}$, istinbăt.

${ }^{1}$ Dosen Studi Islam di Universitas Muhammadiyah Prof. Dr. Hamka Jakarta. E-mail: khalifa_158@yahoo.com 


\section{Pendahuluan}

Agama adalah pedoman hidup manusia. Karenanya ia memberikan informasi bagaimana manusia harus hidup dan menyelesaikan persoalan kehidupannya, sedang informasi yang didapatkan manusia hanyalah yang berbentuk teks. Dengan kata lain, teks agama adalah sarana interaksi antara Allah sebagai Tuhan yang memberikan aturan dan manusia yang melaksanakan at uran tersebut. Teks tidak akan lepas dari realitas yang menyertainya, ${ }^{2}$ karena teks tidak ada yang muncul tanpa adanya suatu kejadian yang menyertainya sebagai sebab ataupun kisah di mana teks itu muncul. ${ }^{3}$ Di sisi lain, maksud realitas tidak hanya mengacu pada realitas di mana teks itu muncul, akan tetapi juga realitas saat di mana teks itu akan digunakan. Di sini kemudian menjadi pilihan bagi seorang pembaca teks atau mufassir adalah dengan bersikap objektif sebagai bentuk independensi teks ataukah subjektif mufassir akibat keterikaitan dengan ruang dan waktu yang berbeda dengan kondisi sang pembuat teks ataupun sebab kemunculan sebuah teks.

Secara umum hukum sebagai produk ijtihad diproses melaui tiga komponen yaitu: pertama, fiqh nuṣuṣ yakni realita teks agama yang ada baik alQuran, hadis ataupun hasil ijtihad ulama. Kedua, fiqh wäqi' yakni realitas yang terjadi di mana teks itu akan diaplikasikan, ketiga, fiqh tanzīl yakni proses penempatan teks kepada realitas sebagai jawaban terhadp problem yang ada. ${ }^{4}$

Nahdlatul Ulama (selanjutnya disebut NU) dalam tulisan ini juga tidak terlepas dari perdebatan itu. Yang menjadi pertanyaan adalah apakah benar NU selama ini sengaja tidak mendasarkan tradisi pemikirannya kepada al-Qur'ān dan sunnah secara langsung guna menghindari pemikiran yang objektif dalam interpretasi tunggal terhadap teks. Di sisi lain, subjektifisme penafsiran sebagaimana yang dimaksud bukan hanya pada sebab di mana teks itu muncul, namun yang dimaksud adalah sebab (latar belakang) ketika teks itu akan diaplikasikan dalam suatu keputusan. Bagaimanapun Islam telah memiliki sejarah pergeseran hukum terkait dengan perbedaan realitas bukan hanya hari ini namun sejak ia muncul pertama kali dibawa oleh Muhammad sebagaimana dalam sejarah pengharaman khamr, ziarah dan sebagainya.

${ }^{2}$ Dalam bahasa Indonesia konteks berarti, Suatu uraian atau kalimat yang mendukung atau menambah kejelasan makna, atau situasi yang ada hubungannya dengan suatu kejadian dengan kejadian atau lingkungan sekitarnya. Lihat Depdikbud, Kamus Besar Bahasa Indonesia (Jakarta: Balai Pustaka, 1988), 458.

${ }^{3}$ Tent unya sebagai keyakinan agama bahwa Allah tidak akan menciptakan sesuatu dengan kesia-sian tanpa adanya keterkaitan dengan sebuah kejadian, lihat misal Ali Imran ayat 191.

${ }^{4}$ Abu Yasid, Nalar dan Wahyu: Interrelasi dalam Proses Pembentukan Syari'at (Jakarta: Erlangga, 2007), 15. 
Karenanya dalam tulisan sederhana ini penulis mencoba meneliti sejauh mana penggunaan teks al-Qur'ān dan hadis dalam menjawab problematika masyarakat sebagai bentuk keberpihakan terhadap teks yang independen itu. Untuk itu, tulisan ini akan mencoba menelisik beberapa buku di antaranya Ahkamul Fuqaha: Solusi Problematika Hukum Islam, Keputusan Muktamar, Munas dan Konbes Nahdlatul Ulama (1926-2004). Buku tersebut adalah kumpulan fatwa-fatwa NU dalam menjawab berbagai masalah baik yang klasik maupun kontemporer yang berjumlah 456 permasalahan.

Tulisan ini bertujuan untuk mengetahui bagaimana NU dalam berinteraksi dengan teks al-Qur'ān dan hadis sebagai sumber pokok dasar hukum Islam untuk memberikan sebuah aturan hukum atau fatwa bagi permasalahan masyarakat. Dari sini kemudian bisa didapatkan sejauh manakah dan dalam problematika bagaimanakah kaum Nahdliyin (sebutan bagi penganut NU) menyandarkan atau mengambil al-Qur'ān dan hadis sebagai bagian dari jawaban problematika tersebut, ataukah bersikap subjektif dengan mengikutsertakan tradisi masyarakat di mana teks itu akan dijalankan sebagai bagian dari pertimbangan hukum.

Buku tersebut di atas pada hakekatnya adalah kumpulan tanya jawab yang muncul dari problematika masyarakat kepada NU sejak tahun 1926 hingga 2004. Sejatinya tujuan pembukuan kumpulan tanya-jawab tersebut adalah untuk menghimpun dan merangkum dokumen-dokumen yang memuat hasil Bahtsul Masail NU yang telah diputuskan melalui Muktamar, Musyawarah Nasional Alim Ulama dan Konferensi Besar NU tahun dari 1926 hingga 2004.

Buku yang diterbitkan atas kerjasama Pimpinan Wilayah Lajnah Ta'lif Wan Nasyr (PW LTN) NU Jawa Timur sendiri mengungkapkan adanya ketidaklengkapannya. Keadaan tersebut berkenaan dengan dua hal; pertama, tentang kelengkapan hasil keputusan Bahtsul Masail NU dari beberapa masa, seperti hasil Muktamar ke-17 Mei 1947, Mukatamar ke-18 Mei 1950 dan Muktamar ke-19 April 1952. ${ }^{5}$ Kedua, upaya klasifikasi sesuai dengan tema dan bab yang sesuai dengan masalah yang diputuskan. Meskipun demikian untuk permasalahan kedua, agaknya penyunting buku ini telah memberikan solusi di akhir buku dengan menyuguhkan tema masalah sesuai dengan nomor dan halaman dalam buku tersebut. Hal ini guna mempermudah pembaca dalam melihat permasalah secara komprehensif yang saling terkait. ${ }^{6}$ Untuk itulah

${ }^{5} \mathrm{Hal}$ ini, dengan alasan tidak diketemukannya dokumentasi keputusan Bahtsul Masail NU pada kegiatan tersebut. Lihat PW LTN NU Jatim, Ahkamul Fuqaha; Solusi Problematika Hukum Islam, Keputusan Muktamar, Munas dan Konbes Nahdlatul Ulama (1926 - 2004) (Surabaya: Khalista dan LTN NU, 2007), xix

${ }^{6}$ PW LTN NU Jatim, Ahkamul Fuqaha, 727-743. 
sebenarnya buku ini sudah cukup mumpuni untuk membaca sejauh mana pembacaan NU terhadap problematika masyarakat dan keterkaitannya dengan teks-teks agama sebagai bagian dari dasar keputusan solusi atas permasalah tersebut. Walaupun yang perlu diperhatikan bahwa yang dimaksud dengan teks dalam tradisi NU bukan hanya sekedar al-Qur'ān dan hadis semata, namun juga teks-teks para ulama klasik, yang dalam tradisi NU disebut sebagai Kitab Kuning.

Selain buku tersebut, tentunya penulis juga akan menelusuri beberapa sumber lain terkait pembacaan NU terhadap al-Qur'ān dan hadis guna memperoleh data lebih luas. Adapun pemilihan terhadap buku primer di atas sebagai sumber utama adalah karena buku tersebut yang penulis anggap paling kredibel untuk merepresentasikan suara atau gagasan NU sebagai organisasi terhadap persoalan keagamaan, yang dalam hal ini juga terkait dengan penggunaan al-Qur'ān dan hadis sebagai sumber hukum.

Sebelumnya memang sudah ada upaya yang membahas tentang Bahtsul Masail NU ini yang menurut penulis cukup komprehensif yakni Ahmad Zahro dalam disertasinya yang kemudian dibukukan dengan judul Lajnah Bahtsul Masail 1926-1999; Tradisi Intelektual NU. Buku tersebut secara umum membedah Bahtsul Masail dari perspektif tradisi uṣūl al-fiqh NU mulai metode, sumber atau rujukan, dan mazhab NU yang tergambar dalam Bahtsul Masail tahun 1926 hingga 1999. Selain itu, tentu pula merujuk pada buku lain yang berkaitan.

Dari berbagai buku tersebut kemudian akan ditelisik bagaimana pemahaman atau penafsiran yang digunakan sebagai gambaran bagaimana NU dalam memahami teks dasar Islam yakni al-Qur'ān dan Sunnah. Tujuan inilah yang menjadi jembatan awal untuk mengetahui bagaimana metode interpretasi teks terhadap probelatika masalah umat yang nantinya akan dikaitkan dengan pemaknaan subjektif dan objektif dalam penafsiran sebagaimana fokus pembahasan dalam tulisan ini.

\section{Tradisi Sunni NU dan Bahtsul Masail}

Nahdlatul Ulama adalah organisasi yang tidak asing di kalangan Indonesia. Organisasi yang diprakarsai salah satunya oleh Hasyim Asyari ini berdiri pada 31 Januari 1926 dan telah memilih Sunni sebagai mazhabnya, serta Syafi'i sebagai acuan mazhab fikihnya. Walaupun, dalam perjalanannya sebenarnya mengacu mayoritas pada Imam empat mazhab.

\footnotetext{
${ }^{7}$ Ahmad Zahro, Lajnah Bahtsul Masail 1926-1999; Tradisi Intelektual NU (Yogjakarta: LKiS, 2004)
} 
Term Sunni (Ahl al-sunnah wal Jamā'ah yang disingkat; aswaja) secara umum mengikuti pengertian yang dijelaskan oleh Nabi dengan hadis iftirāq yakni hadis yang menjelaskan suatu kondisi umat yang terpecah belah sebagai berikut.

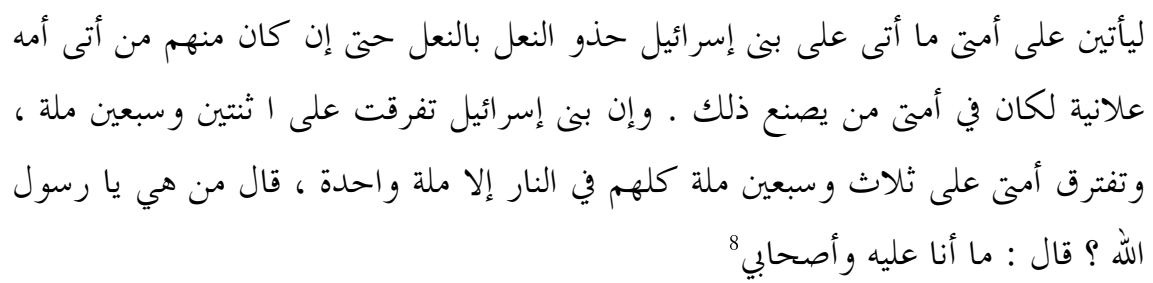

Karenanya, bagi NU interpretasi Aswaja (kependekan dari Ahlu Sunnah wal Jama'ah) yang dalam hadis di atas pada term mā anà 'alaihi wa aṣhâa $\bar{i}$ adalah dengan mengikuti metode berfikir atau manhaj fikr yang dalam hal akidah meraka mengikuti mazhab Abū Hasan al-Asy'ari (260-324 H) dan Abū al-Mansur al-Maturidi (w. $333 \mathrm{H}$ ), di dalam fikih mengikuti salah satu imam empat; Abū Hanifah al-Nu'mān (80-150 H), Muhammad bin Idris al-Syafi' $\bar{i}$ (150-204 H), Mālik bin Anas (93-179 H) dan Ahmad bin Ḥanbal (164-241 H). Walaupun dalam kenyataan di lapangan, al-Syafi'i sebenarnya menjadi prioritas di antara yang lain. Sementara dalam tasawuf bermazhab pada Imām al-Ghazāli (450-505 H) dan Imām Abū Ḥasan al-Syadzili. ${ }^{9}$

Terkait dengan ke-Sunni-an NU dalam memahami ahlu al-sunnah wal jamā'ah agaknya saat ini mengalami pergeseran, di mana, pada mulanya dimaknai kepada keterkaitan mazhab akidah, fikih, dan tasawuf sebagaimana di atas, kemudian baru-baru ini banyak upaya yang dilakukan untuk merevitalisasikannya sebagai bentuk yang lebih modern. Salah satunya adalah apa yang diungkapkan Gus Dur bahwa ahlu al-sunnah wal jamā'ah saat ini memerlukan tiga fondasi lain yakni; pertama, pandangan bahwa keseluruhan hidup adalah ibadah; kedua, perlunya kejujuran dalam kehidupan bermasyarakat dalam rangka mewujudkan toleransi atas perbedaan pendapat; dan ketiga,

${ }^{8}$ Abū Īsa Muhammad al-Tirmidhi (209-279 H), Sunan al-Tirmidhi (Kairo: Dar alFikr, tt), juz 4,135.

${ }^{9}$ Lihat lebih lanjut Zamakhsyari Dhofier, Tradisi Pesantren Tentang Pandangan Hidup Kyai (Jakarta: LP3ES, 1982), 148-150, bandingkan dengan Zuhairi Misrawi, Hadratus Syaikh Hasyim Asy'ari; Moderasi, Keumatan, dan Kebangsaan (Jakarta: Kompas, 2010), 107; data lain dari Ahmad Zahro menyatakan bahwa dalam hal tasawuf mengikuti Junaid al-Baghdadi (w. 297 H), lihat Ahmad Zahro, Lajnah Bahtsul Masail 1926-1999,19. 
perlunya moralitas yang utuh dan kuat demi terbentuknya ahlu al-sunnah wal jamā'ah yang rahmatan lil 'ālamin. ${ }^{10}$

Persepsi Gus Dur tersebut bisa difahami manakala memang term Sunni tidak hanya melekat pada tradisi NU semata. Bahkan Sunni yang dengan bertumpu pada pandangan ahlu al-sunnah wa al-jama'ah telah muncul dengan berbagai variannya. Ada di antara mereka yang memang muncul dalam bentu Sunni yang cukup tekstualis bahkan radikal seperti Wahabi atau bahkan ada pula yang tetap mengaku Sunni namun terbentuk dalam term liberal seperti JIL di Indonesia yang juga menyebut dirinya sebagai aswaja. Walapun harus diakui bahwa Syi'ah sekalipun yang diakui berlawanan dengan Sunni tetap mengakui diri mereka sebagai ahlu al-sunnah wa al-jama'ah.

Karena hal tersebut di atas, maka diperlukan suatu formasi yang utuh ataupun tetap sebagai pegangan siapakah yang patut disebut sebagai golongan yang masuk dalam kategori aswaja atau bukan. Hal ini guna memilah manakah yang memang mengaku bagian dari aswaja namun perilakunya tidak aswaja, ataukah ada pula yang mengaku bukan aswaja tapi perilakunya mengikuti aswaja. Untuk menunjukkan identitas aswaja dan non-aswaja menurut Noer Iskandar al-Barsany, seorang anggota tim aswaja PBNU, adalah dengan melihat kriteria dasar akan ketetapannya pada kaidah sunnah dengan mendahulukan nas dari pada akal atau تقديم النقل على العقل. Sebagai contoh, apa yang diungkapkan Imām Ghazāili pada pendapatnya tentang tasawuf bahwa maqāmat tertinggi adalah ma 'rifat bukan wahdat al-wujüd karena hal itu sudah keluar dari nas. ${ }^{11}$

Sebagai organisasi yang mengemban tanggung jawab terhadap problematika masyarakat maka dibangunlah sebuah lembaga kajian bernama Lajnah Bahtsul Masail (selanjutnya disebut LBM). Menurut Anggaran Dasar dan Anggaran Rumah Tangga (AD/ART) NU dikatakan bahwa LBM bertugas membahas dan memecahkan masalah yang maựū'iyah (tematik) dan wäqi'iyah (aktual) yang memerlukan kepastian hukum. ${ }^{12}$ Kegiatan ini dilakukan secara hirakis mulai tingkat cabang, wilayah hingga pusat dalam forum muktamar. Karenanya keputusan-keputusan yang ada di dalamnya menjadi acuan atau daya ikat yang kuat bagi warga NU, walaupun kadang dalam aplikasi di lapangan warga NU lebih mengikuti pendapat kyai dari pada keputusan LBM NU. ${ }^{13}$ Di samping karena kurangnya sosialisasi yang dilakukan LBM sendiri kepada

\footnotetext{
${ }^{10}$ Zuhairi Misrawi, Hadratu Syaikh Hasyim As'ari, 135-136

${ }^{11}$ Ahmad Zahro, Lajnah Bahtsul Masail 1926-1999, 50

${ }^{12}$ Lihat AD ART NU (Jakarta: PBNU, 2004), 15

${ }^{13}$ Perdebatan ini bisa dilihat pada tulisan Ahmad Munjih Nasih, "Bahtsul Masail dan Problematikanya di Kalangan Masyarakat Muslim Tradisional”, Jurnal al-Qanun, Vol. 12, No. 1, 2009, 107-110
} 
warga NU, bahkan tidak sedikit pula kyai NU yang tidak mengetahui keputusan tersebut. ${ }^{14}$

Dalam menjalankan tugasnya LBM NU memiliki tiga prosedur ${ }^{15}$ yakni taqrï jamā'iy, ilhaq, dan istinbăt. Maksud dari prosedur yang pertama atau taqrir jama'iy adalah menjawab permasalahan dengan cukup mengutip qaul ulama yang dipandang cukup relevan dalam menjawab permasalahan tersebut. Prosedur ini dilakukan secara hirarki dalam pengambilan pendapat sebagaimana berikut:

a. Pertama diambil adalah pendapat yang telah disepakati oleh Imam Nawawi dan Imam al-Rafi'iy.

b. Kedua pendapat Imām al-Nawāwī.

c. Ketiga pendapat Imām al-Rafí'iy.

d. Keempat pendapat yang didukung oleh mayoritas ulama.

e. Kelima pendapat ulama terpandai, dan keenam pendapat ulama yang paling wara'. ${ }^{16}$

Namun dalam hal ini Ahmad Munjih memberikan beberapa kritik. Pertama, penempatan Imam Nawawi lebih dahulu dari Imam Syafi'i dianggap telah mereduksi Imam Syafi'i sebagai founding mazhab. Kedua, karya besar Imam Nawawi seperti al-Majmū' Sharh al-Muhadhdhab, karya Imam al-Rafi'iy seperti al-Muharrar, bahkan al-Umm karya Imam Syafi'i sendiri sangat jarang dipakai rujukan. ${ }^{17}$ Tentunya kedua kritik ini perlu difahami bahwa memang dalam tradisi NU pemahaman terhadap teks dasar Islam seperti al-Quran dan hadis bukanlah suatu yang mudah untuk difahami oleh setiap orang. Karenanya pemahaman para ulama yang mumpuni dan paling dekat dengan masayarakat pembaca yang dalam hal ini NU adalah sebagai solusinya. Karena itulah tradisi syarah kitab -bahkan melakukan syarah terhadap suatu kitab syarah- adalah

\footnotetext{
${ }^{14}$ Sebagaimana yang diungkapkan Said Aqiel al-Munawar dalam "Kata Pengantar", dalam Ahmad Zahro, Lajnah Bahtsul Masail 1926-1999, xv.

${ }^{15}$ Pemilihan kata prosedur ini untuk membedakannya antara metode. Yang membedakamn antara keduanya menurut penulis adalah tentang adanya tahapan, di mana prosedur selalu memberikan tahapan sebagaimana dalam tradisi NU di atas, sedang metode kadang tidak membutuhkan tahapan.

${ }^{16}$ Lebih jelasnya pada Aziz Masyhuri, Hasil Muktamar dan Munas Ulama NU tahun 1926-1994 (Surabaya: Dinamika Press, 1997).

${ }^{17}$ Lihat Ahmad Munjih, Bahtsul Masail dan Problematikanya, 119-120. Bahkan menurut Ahmad Zahro peringkat pertama dalam rujukan adalah kitab I'anat al-Talibin karya al-Bakri ibn Muhammad Shata al-Dimyati. Lihat Ahmad Zahro, Lajnah Bahtsul Masail 1926-1999, 152. Di samping itu dalam buku Aḥkām Fuqahā' ditelaah dalam tulisan ini pun agaknya tidak juga berbeda.
} 
tradisi yang memang masih dibawa NU hingga hari ini untuk mengikuti para ulama terdahulu.

Metode kedua adalah ilhạq, yakni ilhạq al-masà'il bi mazāhirihā (menganalogikan suatu masalah dengan masalah yang menyerupainya). Secara esensi ilhăq tidak jauh dengan qiyās, namun, bedanya qiyās adalah mencarikan perumpamaan persoalan kepada teks al-Qur'ān dan hadis, sedangkan ilhāq adalah mencarikan perumpamaan persoalan kepada pendapat-pendapat para ulama dalam kitab yang ada. Bagi NU sebenarnya tiap permasalahan saat ini jika dicarikan analogi dari al-Quran dan hadis yang muncul pada abad 6-8 $\mathrm{M}$ tentu bukan solusi yang benar. Hal ini bisa difahami dengan dua hal, pertama bahwa ulama tidak hanya hadir hari ini, karena itu al-Quran bukanlah hal baru yang harus difahami orang saat ini secara langsung tanpa melihat bagaimana ulama pendahulu juga memahami al-Quran. Kedua, karena adanya perkembangan zaman dan perubahan problematika sesungguhnya persoalan hari ini akan sangat mungkin dianalogikan dengan masa yang lebih dekat dengan saat ini yang sudah pula dibahas oleh para ulama pendahulu tersebut.

Namun dalam hal ini Ahmad Munjih juga memberikan beberapa kritikan. Pertama menunjukkan ketidakberanian ulama NU untuk merujuk kepada sumber-sumber awal syari'ah, dan kedua seringkali terjadi pemaksaan kepada hal yang tidak lagi sesuai dengan perkembangan zaman. ${ }^{18}$ Persepsi ini tentu muncul karena memang jarangnya NU merujuk kepada al-Qur'ān dan sunnah secara langsung. Namun ungkapan ketidakberanian ini perlu pula difahami bahwa bagi NU tidak sembarang orang dianggap mampu untuk memahami alQur'ān dan sunnah secara langsung. Untuk itu diperlukan penjelasan dari para ulama yang lebih dekat dan lebih memahami tentang interpretasi al-Qur'ān dan sunnah.

Adapun metode ketiga adalah istinbät. Bagi NU istinbāt yang dimaksud bukanlah untuk mengambil kesimpulan hukum secara langsung dari sumber hukum awal yakni al-Qur'ān dan hadis sebagaimana yang difahami dalam kaidah ushul fiqh, tetapi yang dimaksud istinbat dalam tardisi NU adalah mengambil hukum dengan cara memperlakukan secara dinamis nash-nash dalam kitab kuning yang telah dirumuskan para ahli kepada persoalan waqi'iyah untuk dicarikan hukumnya. Hal ini muncul sebagai tahapan ketiga ketika tidak terdapat secara tekstual apa yang menjadi persoalan modern. Seperti tentang kloning, tentu tidak ada nash dalam tradisi kitab kuning yang pernah membahas hal tersebut. Namun bagi NU, walaupun tidak ada nash yang secara langsung membahas tentang masalah tersebut, namun esensi perdebatan atau kaidah

${ }^{18}$ Ahmad Munjih, Bahtsul Masail dan Problematikanya, 121-122. 
ushulnya tetap dan pastilah ada dalam perdebatan ulama klasik. Esensi-esensi tersebut seperti perzinaan, pembunuhan, kekeluargaan dan sebagainya.

Dari ketiga prosedur dalam pengambilan hukum di atas nampaklah bahwa NU masih sangat tergantung kepada nash kitab kuning, yang menurut Sahal Mahfuz, sebagai Ra'is 'Am NU, masih bersifat literal qauli (tekstual) dan belum menyentuh metodologi atau manhaji (konteks). Yang dalam hal ini Sahal Mahfuz mengatakan bahwa fikih sosial adalah jembatan yang menghubungkan antara keangkuhan teks dan tuntutan realitas atau konteks di mana teks akan diterapkan. ${ }^{19}$ Artinya, saat ini subjektifitas seorang mufassir dalam memandang problematika masyarakat bisa dianggap lebih penting dari sekedar objektifitas teks yang terikat oleh ruang dan waktu di mana teks itu muncul. Pemaknaan manhaji dengan subjektifisme ulama klasik memang perlu difahami lebih lanjut. Bahwa kondisi umat pada masa ulama klasik menjadi pertimbangan untuk mengambil sebuah hukum adalah benar, namun bagaimana cara pengambilan hukum terhadap teks awal atau al-Quran dan hadis oleh para ulama tersebut serta kaitannya permasalah kontemporer inilah yang dimaksud dengan konteks dalam kategori manhaji. Dengan demikian dapat difahami bahwa prosedurprosedur yang dilakukan oleh NU belum mengarah ke sana yang artinya masih sangat terpaku pada teks-teks klasik atau kitab kuning.

Oleh karena itu haruslah ada upaya pemahaman subjektif ulama yang berbentuk pada teori bahwa bermazhab yang disimpulkan oleh NU secara qauli adalah hal yang belum final hingga kemudian melangkah ke tahap manhaji. Karena bagaimanapun kemodernan teks klasik atau permasalahan yang dibahas di dalamnya tidaklah akan pernah sama kala diberikan kepada permasalahan kontemporer. Alih-alih untuk mengatakan bahwa NU memang lebih cenderung melakukan taqlid, yang dalam bahasan ini disebut prosedur qauli.

Walaupun, ada beberapa catatan mengenai hal ini, metode manhaji sebenarnya dianggap sudah dilaksanakan oleh LBM NU walaupun nampaknya masih sangat jarang. Ahmad Zahro misalnya, dari analisis yang lakukan bahwa dari 428 kasus yang pernah ditangani oleh LBM NU sejak 1926-1999 memberikan data sebagai berikut: 362 kasus (84.6\%) diselesaikan dengan metode qauli, 33 kasus (7.7\%) dengan metode ilhāqi, dan hanya 8 kasus $(1.9 \%)$ dengan metode manhaji. ${ }^{20}$ Dengan pengertian bahwa manhaji yang dimaksud

\footnotetext{
${ }^{19}$ Mahsun Mahfuz dan Baedhowi, "Mencermati Perkembangan Pemikiran Hukum Islam di Indonesia; Studi Apresiatif atas Pemikiran KH. MA. Sahal Mahfudh tentang Fikih Sosial", Jurnal edisi 7 vol. iv April 2008, 56-57.

${ }^{20}$ Ahmad Zahro, Lajnah Bahtsul Masail 1926-1999, 154. Adapun penggunaan metode taqriri jama'i menurut Ahmad Zahro bukanlah metode istimbat namun sekedar metode dalam pelaksanaan istinbat hukum.
} 
adalah mengikuti para ulama mazhab dalam bermanhaj yakni dengan mencarikan jawaban terlebih dahulu pada al-Qur'ān kemudian hadis, baru jika tidak ada maka diperhatikan pendapat para Sahabat, ulama dan sebagainya sesuai dengan metode para Imam mazhab. Walapun penulis sendiri tidak menemui manakah yang dimaksud oleh Ahmad Zahro masuk dalam kategori manhaji, penulis beranggapan bahwa metode manhaji yang dilakukan oleh NU bukanlah manhaji sebagaimana yang dilakukan oleh para Imam Mazhab, namun hanya karena memang jawaban itu sudah gamblang dijelaskan dalam al-Qur'ān ataupun hadis sehingga tidak perlu lagi pemahamn ulama untuk diambil sebagai hujjah. Hal ini pun setidaknya menjadi catatan tersendiri terhadap keotentikan terhadap kesimpulan Ahmad Zahro mengenai manhaji yang dilakukan oleh LBM NU.

Lebih jauh sebenarnya Achmad Siddiq yang pernah menulis Khittah Nahdliyyah memberikan isyarat penjelasan sederhana bagi warga NU. Pertama, bagi yang memenuhi syarat dan sarana untuk mengambil kesimpulan pendapat atau istinbat. Kedua, bagi yang tidak mampu atau memenuhi maka wajib baginya untuk melakukan taklid, karena, memaksa seseorang istinbat bukan hanya tidak tepat tapi pasti membahayakan bagi umat Islam. ${ }^{21}$ Oleh karena itu, banyak dari kalangan Nahdliyin lebih mengacu pada para Kyai dari pada teks.

Namun dalam golongan pertama harus diakui bahwa syarat untuk mencapai seorang mujtahid saat ini bagi NU sendiri terlalu sulit. Oleh karena itu, melakukan taklid kepada ulama yang diyakini punya prasyarat-prasyarat tersebut tentu lebih baik dari pada mengambil kesimpulan tanpa ilmu. Hal ini sebenarnya agak sejalan dengan apa yang disampaikan oleh Nabi bahwa, "Siapa yang berbicaya sesuatu tentang wahyu Allah dengan pendapatnya sendiri (tanpa ilmu) kemudian ia benar, maka sesungguhnya ia telah melakukan kesalahan. ${ }^{922}$ Hal ini karena bagaimanapun seseorang tanpa ilmu ia tidak akan pernah tahu apakah keputusannya atau perbuatannya itu salah atau benar.

Dengan demikian nampaklah bahwa Bahtsul Masail NU masih sangat terpaku pada teks atau nash-nash klasik, namun bukan pada al-Qur'ān dan hadis. Nash-nash klasik itu terhierarkis kepada yang paling dekat dari pelaku istinbat hukum. Karena itu pula masyarakat NU lebih dekat kepada para kiyai mereka karena kiyai adalah para ulama, sedang para ulama inilah pewaris Nabi yang membawa keilmuan dan pengetahuan agama Islam. Hal ini bisa

\footnotetext{
${ }^{21}$ Lebih jelas lihat Acmad Siddiq, Khittah Nahdliyyah (Surabaya: Khalista, 2005), 36-37.

22 Redaksi hadis ini bisa dilihat di Abu Isa Muhammad al-Tirmidhi, Sunan alTirmizi, Juz 5, 50. Walaupun al-Tirmidhi menghukumi hadis ini gharib, namun esensinya tetaplah bisa diterima sebagai bentuk kehati-hatian dalam berpendapat atau berijtihad.
} 
dibandingkan di Indonesia misalnya pada Muhammadiyah yang relatif tidak menganggap adanya karismatik atau kesakralan seorang kyai. Karenanya di Muhammadiyah hampir tak banyak pimpinannya disebut dengan kyai sebagaimana yang ada pada kultur NU.

\section{Al-Qur'ān dan Hadis dalam Lajnah Bahtsul Masail NU}

Secara sederhana penulis mendapati dalam buku Ahkamul Fuqaha: Solusi Problematika Hukum Islam, Keputusan Muktamar, Munas dan Konbes Nahdlatul Ulama (1926-2004) terdapat 456 permasalah. ${ }^{23}$ Dalam menjawab berbagai persoalan NU dalam buku tersebut menggunakan 71 hadis dari berbagai riwayat seperti Abū Daūd, Tirmīini, al-Baihaq̄i, Bukhari, Muslim, Tabrani, Ibn Mājah, Aḥmad, dan al-Nasa'i. Sedangkan dalam penggunaan ayat al-Qur'ān dalam buku tersebut menggunakan kurang lebih 44 kali dalam berbagai variannya.

Perhitungan penulis di atas mengindikasikan seberapa jauh penggunaan al-Qur'ān dan hadis dalam menjawab berbagai pertanyaan yang muncul. Bagaimana al-Qur'ān dan hadis dianggap sebagai sumber hukum yang baik secara tersurat maupun tersirat menjadi hudan atau petunjuk pada setiap masalah. Yang dalam buku tersebut jika dipresentasikan hanya $16 \%$ dari berbagai pertanyaan tersebut yang menggunakan literatur hadis dalam bentuk matan hadis, sedangkan al-Quran hanya digunakan kurang dari 11\% dari 456 persoalan yang telah dibahas oleh LBM NU.

Hal lain yang menarik dari buku tersebut adalah adanya pernyataan tentang pelarangan untuk berhukum langsung kepada al-Qur'ān dan hadis. Pelarangan ini tentu tidaklah muncul dengan tanpa sebab ataupun tanpa alasan. Persoalan ini muncul ketika adanya sebuah pertanyaan tentang maraknya masyarakat yang menginginkan untuk langsung menjadikan al-Qur'ān dan hadis sebagai dasar hukum Islam tanpa melalui buku-buku atau ulama fikih. Hal tersebut muncul juga karena adanya beberapa ayat yang menyatakan bahwa siapa yang tidak berhukum selain al-Qur'ān adalah perbuatan zalim, fasik, bahkan kafir sebagai berikut:

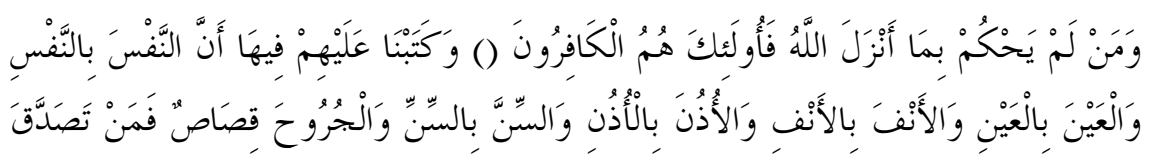

\footnotetext{
${ }^{23} \mathrm{Hal}$ tersebut sesuai yang tertera dalam daftas isi. Hal ini berbeda dengan apa yang dikumpulkan oleh Ahmad Zahro yang dalam disertasinya hingga 505 keputusan. Lihat lebih lanjut, Ahmad Zahro, Lajnah Bahtsul Masail 1926-1999, 71-72
} 


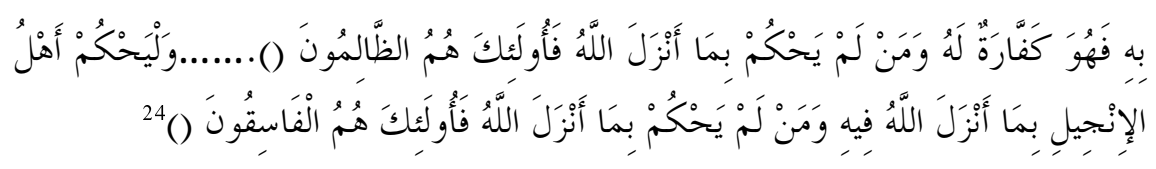

Karena itulah secara jelas dan tegas para perumus Lembaga Bahtsul Masail NU menjawab bahwa yang demikian itu tidak boleh, bahkan dianggap sesat menyesatkan. Dalam hal ini LBM NU memberikan argumentasi dengan upaya ilhăqi yakni mengutip sebuah kitab klasik secara langsung tanpa memberikan perdebatan atau tambahan lain dengan jawaban sebagaimana yang ada dalam kitab Tanwïrul Qulūb.

Dan barang siapa tidak mengikuti salah satu dari mereka (imam-imam mazhab) dan berkata, "Saya beramal berdasarkan al-Qur'ān dan hadis," dan mengaku telah mampu membaca hukum-hukum al-Qur'ān dan hadis, maka orang tersebut tidak bisa diterima, bahkan termasuk orang yang bersalah, sesat dan menyesatkan, terutama pada masa sekarang ini di mana kefasikan merajalela dan banyak tersebar dakwah-dakwah yang salah, karena ia ingin mengungguli para pemimpin agama padahal ia di bawah mereka dalam ilmu, amal, keadilan dan analisis. ${ }^{25}$

Inilah yang menjadi patokan kenapa NU selama ini lebih terfokus kepada kitab-kitab mazhab fikih terutama empat Imam, terkhusus Syafi'i. Al-Qur'ān dan hadis tidak dapat diambil kesimpulan hukum kecuali siapa di antara mereka yang memiliki ilmu yang mumpuni untuk mendalaminya. Jawaban tersebut di atas juga penulis temukan pada sebuah pertanyaan yang hampir sama yakni, bagaimana hukum orang yang menjalankan apa yang tersebut dalam al-Qur'ān dan hadis menurut arti yang tidak sebenarnya, sehingga bertentangan dengan empat mazhab? Dan jawaban dari Tanwirul Qulüb sebagaimana di atas itu pun menjadi dasarnya.

Pelarangan seseorang berhukum tanpa mazhab, NU mendasarkan pada sebuah pertanyaan yang pernah diajukan kepada Ali al-Khawash. Pertanyaan ini terlukis pada buku al-Mīzān al-Sha'rani, Fatwā Kubrā dan Nihāyatussūl. Di situ disebutkan bahwa Ali al-Khawash pernah ditanya seseorang tentang mengikuti mazhab tertentu apakah wajib atau tidak? Ia menjawab bahwa hal tersebut adalah wajib bagi mereka yang belum sampai mengetahui inti agama karena khawatir sesat dan menyesatkan. ${ }^{26}$ Artinya bahwa kewajiban bermazhab dan mengikuti mazhab yang difahami NU adalah dengan cara mengikuti faham dan

\footnotetext{
${ }^{24}$ Lihat al-Maidah [5]: 44-47.

${ }^{25}$ PW LTN NU Jatim, Ahkamul Fuqaha; Solusi Problematika Hukum Islam, Keputusan Muktamar, Munas dan Konbes Nahdlatul Ulama (1926 - 2004), 176.

${ }^{26}$ PW LTN NU Jatim, Ahkamul Fuqaha, 2.
} 
pendapat mazhab secara objektif sebagai teks yang independen tanpa adanya perdebatan dan bukan mengikuti bagaimana para ulama mazhab tersebut menentukan sebuah hukum atau keputusan. Tentunya, hal ini bisa difahami karena memang para ulama mazhab menganggap bahwa al-Qur'ān dan hadis adalah sumber otentik yang pertama kali harus menjadi patokan dan bukan pendapat para ulama.

Jawaban lain dari kewajiban mengikuti mazhab ini juga tertuang pada

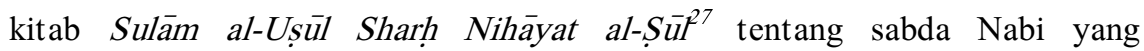
memerintahkan ittabi'u al-sawād al-a'zam ${ }^{28}$ yang berarti ikutilah pendapat mayoritas. Dalam memahami hadis tersebut, penulis buku Sulām al-Uṣūl berpendapat bahwa ketika mazhab-mazhab yang benar telah tiada, dengan wafat para imamnya, kecuali empat mazhab yang pengikutnya tersebar dengan luas, maka mengikuti mazhab empat tersebut berarti mengikuti mayoritas, dan keluar dari empat mazhab tersebut berarti keluar dari mayoritas. Tentunya, yang dimaksud di sini adalah mengikuti pendapat mereka tentang suatu hukum syar'i bukan mengikuti bagaimana mereka menentukan suatu hukum syar'i, yang dalam prosedur istinbat hukum oleh LBM NU disebut sebagai manhaji.

Dengan kata lain, mengikuti salah satu di antara empat mazhab adalah wajib hukumnya, yang kemudian bagi NU, Syafi'i adalah pilihannya. Hal tersebut dapat dilihat dari kata pengantar dari Sahal Mahfudh selaku Ra'is Am PB NU berikut:

Hampir bisa dipastikan bahwa fatwa, petunjuk dan keputusan hukum yang diberikan oleh ulama NU dan kalangan pesantren selalu bersumber pada mazhab Syafi'i. Hanya kadang-kadang dalam keadaan tertentu untuk tidak terlalu melawan budaya- berpaling ke mazhab lain. ${ }^{29}$

Dengan kata lain, pernyataan di atas mengindikasikan bagaimana sikap objektifisme NU terhadap teks kitab klasik dan bukan pada al-Quran dan hadis. Namun, juga perlu diperhatikan bahwa dalam keadaan tertentu, sikap subjektifisme NU terhadap teks itu juga muncul saat teks tersebut dihadapkan dengan kultur budaya dan tradisi yang berbeda, bahkan bukan dari agama Islam. Contoh yang sering muncul misalnya tentang peringatan kematian pada hari ke $3,7,40,100$, dan $1000 .^{30}$

${ }^{27}$ PW LTN NU Jatim, Ahkamul Fuqaha, 3.

${ }^{28}$ Hadis ini bisa dilihat diberbagai kitab matan seperti, Abū Abdullah al-Hakim alNisaburi, Mustadrak 'Alā Sahiḥain (Beirut: Dar al-Kutub al-Ilmi, 1990), Juz 1, 199; Muhammad Ibn Yazid Ibn Mājah, Sunan Ibn Mājah (Beirut: Dar al-Fikr, tth), juz 2, 1302.

${ }^{29}$ PW LTN NU Jatim, Ahkamul Fuqaha, v.

$30 \mathrm{Hal}$ ini sering disebut acara Slametan. Dalam berbagai versi ada yang mengatakan bahwa hitungan ini berasal dari tradisi Jawa Klasik Hindu-Budha, lihat 
Pernyataan bahwa NU mengikuti pendapat-pendapat mazhab tersebut sebenarnya memberikan peluang bagi NU untuk memiliki keleluasaan dalam memberikan kebijakan dalam setiap masalah. Bahkan, menurut Ahmad Zahro hal inilah yang membuat NU tidaklah rigid (kaku) dan memiliki banyak alternatif dalam setiap permasalahan. ${ }^{31}$ Namun dalam ungkapan akhir di atas juga perlu dipahami bahwa kemungkinan untuk bermazhab selain Syafi'i juga dimungkinkan oleh LBM NU.

Oleh karena itu memang al-Qur'ān dan sunnah bukan jawaban yang khas bagi NU. Dalam beberapa pernyataan lain disebutkan,

Pengertian istinbat al-ahkam di kalangan NU bukan langsung mengambil langsung dari sumber aslinya, yaitu al-Qur'ān dan Sunnah akan tetapi sesuai dengan sikap dasar bermazhab- mentatbiqkan (memberlakukan) secara dinamis nash-nash fuqaha dalam konteks permasalahan yang dicari hukumnya. ${ }^{32}$

Argumen lain yang biasanya menjadi landasan bagi NU adalah tulisan Hasyim Asyari selaku pelopor NU yang menyatakan dalam kitabnya Risālah fì Ta'akkud al-Akhdhi bi Madhahib al-A'immah al-Arba'ah bahwa bermazhab kepada yang empat adalah hal yang paling bermanfaat dengan adanya tiga sebab; pertama, mengacu para ulama salaf adalah konsensus yang telah disepakati pula oleh para ulama; kedua, adanya ayat al-Qur'ān dan hadis Rasul yang menyatakan pentingnya pengikuti pandangan orang-orang mulia dan cerdas sebagai kelompok alternatif yang tidak lagi diragukan ${ }^{33}$; dan ketiga, menghindari adanya klaim-klaim kebenaran yang dilakukan beberapa orang yang mengaku ahli agama. ${ }^{34}$

Tentang menghindari klaim-klaim kebenaran dalam hal ini harus dipahami betapa banyaknya orang merasa mampu secara langsung membaca alQuran dan hadis lalu memberikan keputusan-keputusan pada masyarakat soal ajaran Islam tanpa menengok kepada pendapat para ulama lalu yang lebih mampu dan lebih mengetahui perkembangan perdebatan pemikiran masyarakat.

Ridwan, "Mistisisme Simbolek Pada Tradisi Islam Jawa," Jurnal Ibda, STAIN Purwokerto, Vol. 6, No. 1, 2008. Ada pula yang mengatakan bahwa tradisi ini sudah di bawa oleh Sunan Ampel dari tradisi umat Islam di Champa, sebuah kotakecil di Kamboja.

${ }^{31}$ Ahmad Zahro, Lajnah Bahtsul Masail 1926-1999, 3.

${ }^{32} \mathrm{PW}$ LTN NU Jatim, Ahkamul Fuqaha, ix.

${ }^{33}$ Salah satu ayat al-Quran yang menyebutkan dalam hal ini ada pada al-Nahl [16]: 43 yang artinya, "Dan Kami tidak mengutus sebelum kamu, kecuali orang-orang lelaki yang Kami beri wahyu kepada mereka; maka bertanyalah kepada orang yang mempunyai pengetahuan jika kamu tidak mengetahui."

${ }^{34}$ Zuhairi Misrawi, Hadratus Sayikh Hasyim Asy'ari, 111. 
Pendapat tersebut mengindikasikan bahwa memang al-Qur'ān dan hadis adalah hal yang cukup sakral dan tidak mudah dipahami dalam kaca mata NU, sehingga muncul asumsi untuk terlebih dahulu melihat hasil ijtihad para fukaha yang dianggap kredibel dan otoritatif dalam memberikan interpretasi.

Oleh karena NU memiliki prinsip untuk bermazhab -yang secara umum qauli, walau akhir-akhir ini mulai mengacu pada mazhab manhaji- maka muncullah argumen bahwa saat ini telah tiada seorang mujtahid dalam arti seorang mujtahid mutlak. Artinya, dalam hal ini LBM NU memang menganggap bahwa saat ini tidak ada lagi seorang yang memiliki kemampuan seorang mujtahid mutlak.

Dalam hal ini Abdul Mughits memberikan argumen dengan adanya sebuah hadis yang dianggap membolehkan adanya masa kekosongan (ketiadaan) seorang mujtahid, yang berarti diperbolehkannya, bahkan diharuskannya untuk mengikuti mazhab para mujtahid yang sudah ada. Hadis tersebut berbunyi.

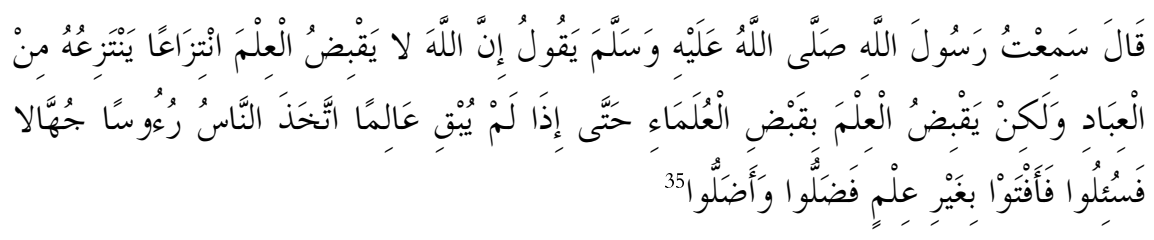

"Sesungguhnya Allah tidak akan mencabut ilmu-Nya dari hamba tatapi mencabut ilmu dari jiwa-jiwa para ulama, sehingga tidak ada lagi orang pandai, orang-orang yang mengangkat pemimpin yang bodoh dan katika ditanya, mereka itu member fatwa tanpa ilmu pengetahuan sehingga sesat dan menyesatkan."

Hadis di atas tersebut kemudian dimaknai bahwa yang hilang adalah para mujtahid pendiri mazhab. ${ }^{36}$

Walaupun demikian, ketika memahami surat al-Nisa [4]: $59^{37}$ Abdul Mughits mengatakan bahwa berijtihad adalah perintah Allah yang masih berlaku. Namun, sebagaimana difahami NU bahwa menemukan ataupun menjadi seorang seorang mujtahid mustaqill atau mutlak bukanlah hal mudah bahkan sangat sulit dan dianggap mustahil. ${ }^{38}$ Hal ini karena dua hal, pertama

\footnotetext{
${ }^{35}$ Muhammad bin Ismail al-Bukhari, Saḥiḥ al-Bukhāri (Beirut: Dar Ibn Kathir, 1407), Juz 1, 50.

${ }^{36}$ Abdul Mughits, Kritik Nalar Fiqih Pesantren (Jakarta: Kencana, 2008), 103-104.

${ }^{37}$ Yang artinya, "Hai orang-orang yang beriman, taatilah Allah dan taatilah Rasul (Nya), dan ulil amri di antara kamu. Kemudian jika kamu berlainan pendapat tentang sesuatu, maka kembalikanlah ia kepada Allah (Al Quran) dan Rasul (sunnahnya), jika kamu benar-benar beriman kepada Allah dan hari kemudian. Yang demikian itu lebih utama (bagimu) dan lebih baik akibatnya."

${ }^{38}$ Abdul Mughits, Kritik Nalar Fiqih Pesantren, 109.
} 
karena sulitnya persyaratan menjadi seorang mujtahid; kedua, karena saat ini ijtihad telah menjadi ijtihad kolektif bagi umat Islam. Maka, ijtihad bisa dilakukan secara jama'iy yang dalam hal ini berbentuk forum seperti LBM NU. Yakni, karena problematika masyarakat yang bervariatif sedang keilmuan mengalami dikotomi, maka tidaklah mungkin menentukan suatu hukum hanya berdasarkan al-Quran dan hadis saja tanpa mengesampingkan kemodernan atau kearifan lokal, yang dalam pembahasan tulisan ini menunjukkan sikap subjektifisme LBM NU dalam memaknai teks agama.

Namun yang kadang menjadi persoalan dan harus dipahami adalah bahwa ulama yang menjadi mayoritas rujukan NU adalah seorang mujtahid murajjih, bahkan mujtahid fi al-fatwa yang sepenuhnya menjadi muqallid mazhab seperi Imam Nawawi $\left(630-676\right.$ H) dan Imam al-Rafi'i (w. 623 H). ${ }^{39}$ Karena itulah kitab-kitab induk milik Syafi'i juga tak banyak menjadi rujukan bagi warga NU, namun hanya mengulang secara objektif dari para ulama yang mengikuti pendapat beliau.

Adapun menurut Ahmad Zahro sebenarnya metode manhaji sudah dilakukan NU sejak lama walaupun belum menamainya. Sebagai contoh ia menyebutkan bahwa dalam muktamar 1926 ketika ditanyakan tentang pahala sadaqah kepada mayit, LBM NU secara langsung merujuk kepada hadis dalam Sahịh al-Bukhāri sebagaimana yang akan dicontohkan di bawah. Ada pula contoh lain tentang hukum mencari rejeki lewat sepak bola, sandiwara dan sebagainya yang kemudian LBM NU memberikan jawaban singkat bahwa jika kegiatan itu haram maka haram pula melakukannya. Kemudian LBM NU memberikan kaidah usul دفع المفاسد مقدم على جلب المصالح.

Dua contoh tersebut, bagi Ahmad Zahro, bisa dimasukkan dalam kategori metode manhaji, yakni metode pengambilan hukum menurut kaidah usul yang dilakukan oleh para imam mazhab. Dalam hal ini, ketika LBM NU dalam menyelesaikan permasalahan tidak menemukan jawabannya dalam kitab mazhab (tidak bisa melakukan qauli ataupun ilhāqi) maka kemudian merujuknya pada al-Qur'ān, jika tidak ada kepada hadis, dan selanjutkan jika masih tidak ditemukan maka akan diberikan kaidah usul sebagaimana yang dipakai oleh para ulama mazhab. ${ }^{40}$ Atau dengan kata lain, LBM NU dalam hal

${ }^{39}$ Adapun tingkatan seorangn mujtahid adalah; a. mujtahid mutlaq atau mustaqil, $b$. mujtahid mutlaq rair mustaqil, c. mujtahid fi al-mazhab, d. mujtahid murajjih, dan e. mujtahid fi al-fatwa. Lihat lebih lanjut, Abdul Mughits, Kritik Nalar Fiqih Pesantren (Jakarta: Kencana, 2008), 95-101. 124-126.

${ }^{40}$ Keterangan lebih lanjut baca, Ahmad Zahro, Lajnah Bahtsul Masail 1926-1999, 
ini menggunakan subjektiftas ulama klasik dan bukan objektifitas teks ulama tersebut.

Berikut ini akan penulis berikan beberapa contoh terkait pengambilan ijtihad fuqaha Syafi'i, al-Qur'ān dan hadis sebagai sumber hukum dalam mazhab NU, tentunya, sesuai dengan apa yang telah dibahas dalam buku Ahkamul Fukaha sebagai berikut:

\section{a. Pengambilan Ijtihad Ulama Syafi'i}

Pada hakekatnya memang tidak semua persoalan baik agama maupun duniawi telah tergambar hukumnya atau aturannya dalam al-Qur'ān. Karena itu, menjadikan ijtihad ulama sebagai sumber dinilai lebih baik dari pada harus berijtihad sendiri tanpa ilmu. Sebagai contoh ketika ditanyakan dalam soal shalat dhuha berjamaah, dalam hal ini NU memberikan fatwa keharaman bagi pelakunya sebagaimana yang dikutip dari buku Bughyat al-Mustarshidin.

"Diperbolehkan berjamaah misalnya pada shalat witir dan tasbih. Dalam hal ini tidak dimakruhkan namun juga tidak berpahala... jika tidak disertai dengan sesuatu yang sangat penting seperti adanya gangguan atau timbulnya keyakinan di kalangan umum tentang disyariatkannya jamaah tersebut. Jika tidak disertai dengan hal tersebut, maka tidak berpahala dan bahkan haram dan harus dilarang."

Contoh lain adalah tentang menyediakan makanan kepada penta'ziyah. Dalam hal ini nampaknya agak berbeda sebagaimana yang terjadi dalam masyarakat, di mana NU memakruhkan keluarga mayit untuk memberikan makanan kepada para penta'ziyah pada hari wafat, ketiga, maupun ketujuh setelah kematian. Walaupun demikian, NU menganggap bahwa kegiatan tersebut tidak menghilangkan pahala sedekah bagi pelakunya. Adapun kemakruhan tersebut didasari pada kitab I'änah al-Talibin yang menyebutkan sebuah riwayat Ahmad yang menyebutkan bahwa Jarir bin Abdullah al-Bajali berkata, "Kami menganggap berkumpul di (rumah keluarga) mayit dengan menyuguhkan makanan pada mereka setelah si mayit dikubur, itu sebagai bagian dari ratapan (yang dilarang)." ${ }^{\prime 2}$

Sedangkan tentang adanya pahala sedekah bagi mayit didasarkan pada sebuah hadis $^{43}$ :

${ }^{41}$ PW LTN NU Jatim, Ahkamul Fuqaha, 196.

${ }^{42}$ PW LTN NU Jatim, Ahkamul Fuqaha, 16. Ada pula hadis dari riwayat Abu Daud

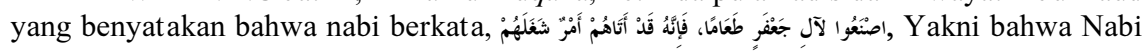
meminta para Sahabat untuk membuat makanan agar diberikan kepada keluarga Ja'far yang meninggal. Lihat, Abu Daud, Sunan, juz 3, 195

${ }^{43}$ PW LTN NU Jatim, Ahkamul Fuqaha, 18. 
Ibu Abbas meriwayatkan, bahwa ada seseorang yang bertanya kepada Rasulullah Saw., "Sesungguhnya ibuku sudah meninggal, apakah bermanfaat baginya (kalau) aku sedekah atas (nama)nya?" Rasulullah menjawab, "Ya," Orang tersebut kemudian berkata, "Sesungguhnya aku memiliki sekeranjang buah, maka aku ingin engkau menyaksikan bahwa sesungguhnya aku menyedekahkan atas (nama)nya."

\section{b. Penggunaan ayat al-Qur'ān}

Al-Qur'ān yang diyakini sebagai kalam Allah tentu menjadi acuan dan segala yang bertentangan dengannya haruslah ditolak. Salah satu hal yang menjadi contoh al-Qur'ān sebagai dasar penetapan hukum di NU adalah tentang penetapan pemimpin non-Islam. Dalam hal ini pernah ditanyakan kepada para ulama NU tentang bagaimana hukum orang Islam yang menguasakan urusan kenegaraan kepada mereka yang non-muslim. Pertanyaan ini kemudian dijawab bahwa orang Islam tidak boleh menjadikan orang non-Islam sebagai pemimpin dengan dasar ayat al-Qur'ān an-Nisā ayat 141. ${ }^{44}$ Bagi LBM NU ayat tersebut menyebutkan pelarangan untuk memberikan kuasa urusan kenegaraan kepada orang non-muslim kecuali dalam keadaan darurat, yakni:

a. Dalam bidang-bidang yang tidak bisa ditangani sendiri oleh orang Islam secara langsung atau tidak langsung karena faktor kemampuan.

b. Dalam bidang-bidang yang orang Islam berkemampuan untuk menangani, tetapi terdapat indikasi kuat bahwa yang bersangkutan khianat.

c. Sepanjang pengusaan urusan kenegaraan kepada non-muslim itu nyata membawa manfaat.

Contoh berikutnya adalah tentang Pandangan NU terhadap Lingkungan Hidup. ${ }^{45}$ Masalah lingkungan memang menjadi persoalan kontemporer yang cukup mendapat perhatian. Karenanya NU dalam hal ini cukup sigap untuk kemudian membuat sebuah cara pandang alam yang lebih holistik. Mengenai

\footnotetext{
${ }^{44}$ Yang artinya (Yaitu) orang-orang yang menunggu-nunggu (peristiwa) yang akan terjadi pada dirimu (hai orang-orang mukmin). Maka jika terjadi bagimu kemenangan dari Allah mereka berkata: "Bukankah kami (turut berperang) beserta kamu?" Dan jika orang-orang kafir mendapat keberuntungan (kemenangan) mereka berkata: "Bukankah kami turut memenangkanmu, dan membela kamu dari orang-orang mukmin?" Maka Allah akan memberi keputusan di antara kamu di hari kiamat dan Allah sekali-kali tidak akan memberi jalan kepada orang-orang kafir untuk memusnahkan orang-orang yang beriman.

${ }^{45}$ Sejauh bacaan penulis nampaknya ada perbedaan dalam pemakaian ulama fikih sebagai sumber hukum pada saat Muktamar NU ke-29 tahun 1994. Perbedaan tersebut nampaknya juga diikuti dengan pola pembahasan yang lebih komprehensif dan lebih banyak mengacu pada al-Quran dan hadis. Lihat PW LTN NU Jatim, Ahkamul Fuqaha, $629-633$.
} 
persoalan yang terkait atau mengambil al-Qur'ān sebagai dasarnya, NU antara lain memberikan pandangan sebagai berikut:

a. Bahwa meningkatkan kualitas manusia harus mengikutsertakan membangun kualitas lingkungan. (Hūd [11]: 61)

b. Sumber kerusakan lingkungan adalah manusia (ar-Rūm [30]: 41)

c. Lingkungan adalah karunia untuk manusia yang penuh dengan makna (Ali Imran [3]: 191)

d. Hubungan manusia dengan alam adalah hubungan yang dibingkai dengan akidah. (an-Nahl [16]: 10-11; Qāf [50]: 9-11; 'Abasa [80]:24-32)

e. Menjaga kelestarian lingkungan dalam Islam adalah wajib (al-Baqarah [2]: 205; al-A'raf [7]: 85)

\section{c. Penggunaan hadis}

Begitu pula dengan hadis, di mana hadis sebagai bagian dari dasar hukum Islam, NU tidaklah mengabaikannya begitu saja. Sebagai contoh yang menjadi bagian dalam buku Ahkamul Fukaha yang dibahas dalam tulisan ini adalah ketika adanya pertanyaan tentang boleh tidaknya seorang perempuan menjadi kepala desa. Dalam hal ini NU memberikan jawaban tidak boleh kecuali dalam keadaan memaksa, sebab disamakan dengan tidak bolehnya perempuan menjadi hakim. ${ }^{46}$ Adapun dalil yang menjadi dasar adalah sebuah hadis yang dipakai oleh Sya'rani dalam bukunya al-Mīzān al-Kubrā yakni: yang berarti, “Tidak akan pernah sukses suatu kaum yang menyerahkan urusannya kepada perempuan"." Selain mengutip hadis tersebut, NU juga memberikan penjelasan akan adanya ketidakbolehan oleh para ulama fikih seperti Syafi'i, Maliki dan Hambali. Walaupun, ada pula ulama fikih yang membolehkannya seperti Hanafi yeng membolehkan dalam urusan harta benda dan Ibnu Jarir yang membolehkan perempuan menjadi hakim.

Adapun permasalahan yang lain yang mengutip hadis sebagai dasar argumentasinya adalah soal shalat di Masjid yang dibangun dengan uang haram. ${ }^{48}$ Dalam menanggapi pertanyaan tersebut NU cukup tegas menjawabnya yakni sah shalatnya, tetapi haram dan tidak dapat pahala shalatnya. Ada sebuah hadis yang menjadi argumentasi dalam persoalan ini yakni.

$$
\text { من اشترى ثوبا بعشرة در اهم فيه درهم حرام لم يقبل الله منه صلاة مادام عليه } 49
$$

${ }^{46}$ PW LTN NU Jatim, Ahkamul Fuqaha, 310-312.

${ }^{47}$ Hadis ini salah satunya diriwayatkan oleh al-Bukhari dari Utsman bin Haitsam, lihat Muhammad ibn Ismail al-Bukhari, Saḥị̣ al-Bukhārí, juz 6, 8.

${ }^{48}$ PW LTN NU Jatim, Ahkamul Fuqaha, 248-249.

${ }^{49}$ Hadis ini bisa dilihat di Abū Bakr Aḥmad Ibn Ḥusain al-Baihaqi, Shu'ab al-İmān (Beirut: Dar al-Kutub al-Ilmi, 1410), juz 5, 142; juga Ạ̣mad Ibn Ḥanbal, Musnad alImām Ahmad Ibn Hanbal (Kairo: Mausu'ah Qurtubi, tth), juz 2, 97. 
Rasul bersabda, "Barang siapa membeli baju seharga sepuluh dirham, satu dirham di antaranya adalah uang haram, maka Allah Swt., tidak akan menerima shalatnya selama ia masih memakai baju tersebut."

Sebagai contoh dalam persoalan kontemporer, NU juga membahas nasb al-imam (kepemimpinan) dan demokrasi. Masalah demokrasi memang hal yang tidak bisa dihindari dalam konteks modern, sedangkan adanya seorang pemimpin adalah konsekuensinya. Untuk itu, NU memberikan argumentasi beberapa hadis nabi sebagai berikut:

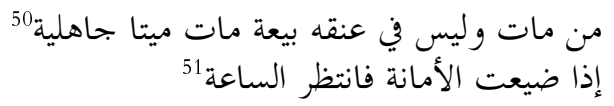

\section{Mengukur Sikap Subjektif dan Objketif LBM NU}

Mengenai objektif dan subjektif sebuah penafsiran, alangkah baiknya jika mendudukkan terlebih dahulu makna ini agar tidak terjadi kesalahpahaman. Bagi Daniel Weinstock misalnya, makna objektif bisa difahami dalam dua segi yakni fact of the matter dan epistemic authority. Yang dimaksud fact of the matter adalah cara pandang bahwa seseorang atau agama telah memberikan panduan untuk melakukan atau tidak terhadap suatu perbuatan, sedangkan epistemic authority adalah bahwa kebenaran dan kesalahan hanya bisa didasarkan pada doktrin agama. ${ }^{52}$

Adapun penafsiran subjektif adalah seseorang memiliki kemampuan atau ijtihad dalam membentuk suatu keharusan. Seseorang bisa saja menerima bahwa agama mengatakan ia harus melakukan $\mathrm{A}$, dan pada saat tertentu seseorang diperbolehkan pula untuk melakukan $\mathrm{B}$, mengingat bahwa tindakan A tidak lagi bisa dilakukan akhibat perbedaan ruang dan waktu. Namun, baik tindakan A maupun B bisa saja memiliki tujuan yang sama. Karena itu, dalam hal ini Weinstock mengajukan untuk read the hearts of claimant agar bisa melakukan interpretasi terhadap suatu doktrin, termasuk agama. ${ }^{53}$

Bagaimanapun Bahtsul Masail NU bukanlah suatu pemikiran yang berhenti, melainkan ia selalu dinamis dalam menyikapi setiap permasalahan. Secara sekilas nampaknya perubahan dalam metode pemahaman teks oleh

\footnotetext{
${ }^{50}$ Hadis ini bisa dilihat pada Muḥammad Ibn Hịban, Saḥị̣ Ibn Hibbān (Beirut: Muassasah al-Risalah, 1993), juz 10, 343.

${ }^{51}$ Hadis ini bisa dilihat pada Abū Bakar Aḥmad al-Baihaqi, Sunān al-Kubrā (Mekah: Maktabah Dar al-Barf, 1344 H), juz 10, 118; Muhammad Ibn Ismail al-Bukhari, Sahih al-Bukhari (Beirut: Dar Ibn Katsir, 1978), juz 5, 2382; juga Ahmad Ibn Hambal, Musnad Ahmad (Riyadh: Muassasah al-Risalah, 1999 M), juz 14, 343.

${ }^{52}$ Daniel Weinstock, "Beyond Objective dan Subjective: Assessing the Legitimacy of Religius Claims to Accomodation," The Ethics Forum, Vol. 6, No. 2 (2011), 159.

${ }^{53}$ Daniel Weinstock, "Beyond Objective dan Subjective," 165.
} 
Bahtsul Masail dari yang awalnya menggunakan qauli kemudian mengarah dan mengalami perubahan kepada manhaji.

Pemakanaan teks agama bagi NU tidak hanya sekedar al-Quran dan hadis, melainkan juga teks para ulama klasik yang dianggap memiliki kapabilitas dalam pembacaan terhadap al-Quran dan hadis. Dari ketiga teks dasar dalam tradisi Islam tersebut, LBM NU nampaknya lebih cenderung berpihak atau mengacu pada teks ketiga yakni penjelasan para ulama klasik yang dianggap lebih mengetahui substansi kedua teks agama yang pertama (alQuran dan hadis).

Fakta di atas dilakukan karena beberapa alasan yang bisa dirangkum dari pembahasan sebelumnya yakni; Pertama ulama klasik atau ulama mazhab dianggap lebih mampu menjelaskan substansi teks al-Quran dan hadis dari pada ulama kontemporer. Kedua, para ulama klasik telah merumuskan kaidah usul yang masih bisa berlaku pada realitas modern. Ketiga, sulitnya menemukan seorang ulama hari ini yang mampu melakukan ijtihad sebagaimana ulama klasik, hal ini dilihat dari masih tergantungnya ulama kontemporer terhadap pendapat ulama klasik. Keempat, perbedaan realitas yang terjadi saat al-Quran dan hadis muncul berbeda dengan masa berikutnya hingga saat ini, karenanya teks agama dalam bentuk al-Quran dan hadis itu tidak akan berarti tanpa penjelasan para ulama, sedang para hasil ijtihad ulama klasik itupun tidak akan berarti tanpa penjelasan ulama berikutnya. Hal keempat inilah yang nampaknya kemudian menjadi kecenderungan warga NU untuk bergantung pada para Kyai. $^{54}$

Dari keempat hal di atas terlihat bahwa pemahaman terhadap metode pembacaan teks agama LBM NU yang berdasar pada metode qauli dengan mengacu pada qaul ulama. Hal inilah yang kemudian melahirkan tradisi NU yang cukup unik dalam menetapkan sebuah jawaban terhadap masalah. Tentu disadari bahwa baik al-Quran, hadis, maupun ijtihad ulama tidaklah lepas dari realita yang terjadi pada saat munculnya terks tesebut. Karena itu, mengutip ucapan Nasr Hamid bahwa budaya tradisi manusia termasuk agama Islam tidaklah serta merta muncul dari teks-teks tersebut, namun selalu bergulat dan bergumul dengan realitas yang terjadi hingga saat ini. ${ }^{55}$ Kemudian disadari ataupun tidak bahwa ungkapan bahwa NU lebih bisa mengikuti tradisi didasari

\footnotetext{
${ }^{54} \mathrm{Hal}$ ini nampaknya sejalan dengan apa yang disampaikan Ali bahwa wahyu adalah teks yang diam, dan untuk menggerakkannya guna bermanfaat dibutuhkan ijtihad. Sedang ijtihad itu adalah interpretasi para ulama. Lihat Abu Yasid, Nalar dan Wahyu: Interrelasi dalam Pembentukan Syari'at (Jakarta: Erlangga, 2007), 4.

${ }^{55}$ Nasr Hamid Abu Zaid, Mafhūm al-Nașs: Dirāsah fi 'Ulūm al-Qur'ān (Kairo: alHaiah al-Mișriyah li al-Kitāb, 1993), 11.
} 
bahwa budaya dan tradisi adalah hal yang juga bisa menjadi bagian dari agama saat ia bercampur dengan ijtihad manusia dalam memaknai teks agama.

Sikap subjektif LBM NU sebenarnya tidak hanya terlihat pada pembacaannya terhadap al-Quran dan hadis semata, namun pada nas para ulama klasik pun bersikap sama. Hal ini terlihat pada bagaimana NU menyikapi persoalan modern seperti lingkungan yang tidak hanya berpaut pada teks para ulama, namun mengembalikannya kepada makna universal tentang penjagaan kelestarian bumi yang terdapat pada teks al-Quran dan hadis. Hal ini menunjukkan bahwa sikap objektif LBM NU tidak selamanya mengacu pada ijtihad para ulama melainkan juga pada sumber awalnya al-Quran dan hadis. Di sisi lain, pembacaan terhadap realitas tradisi masyarakat juga menjadi sikap subjektifitas LBM NU. Tradiri masyarakat Jawa yang sering melakukan ritual agama secara bersama-sama nampaknya lebih bisa dilaksanakan oleh NU dari pada ormas lain dalam bentuk acara Selametan, Tahlilan, Yasinan dan sebagainya. Karenanya banyak tradisi NU dalam sejarahnya lebih bisa mengakomodir tradisi seperti Kejawen dari pada ormas semacamnya.

Demikianlah usaha membumikan teks agama yang dibawa oleh Nahdlatul Ulama. Bagaimanapun NU adalah organisasi yang tida berhenti. LBM NU adalah lembaga yang secara terus menerus mengawasi dan mencoba menjawab peroblematika masyarakat. Pergeseran dari metode qauli kepada manhaji yang diajukan oleh beberapa tokoh NU mengindikasikan bahwa memang realitas modern memang jauh berbeda dengan realitas yang dibawa oleh hasil ijtihad ulama klasik. Karenanya, mengambil dalil dari al-Quran dan hadis yang lebih global dari pada hasil perincian ijtihad ulama kadang menjadi pilihan. Hal ini juga bisa dibuktikan dengan makin banyaknya al-Quran dan hadis yang menjadi dasar dalam persoalan yang dilakukan oleh LBM NU dalam menanggapi masalah kontemporer.

\section{Penutup}

Agama adalah jalan kehidupan bagi manusia dari Tuhan. Karenanya Tuhan telah memberikan panduan kehidupan. Namun, yang menjadi masalah adalah ketika terhentinya dan selesainya interaksi Tuhan dan manusia dalam bentuk wahyu. Nampaknya manusia mulai mencari opsi tersendiri untuk hidup. Ada di antara mereka yang tetap mengikuti panduang ajaran agama dengan tetap meyakini bahwa baik-buruk benar-salah menurut agama adalah baik-buruk benar-salah pula bagi manusia. Sedang ada pula mereka yang menganggap bahwa baik menurut agama, belum tentu baik untuk manusia sehingga manusia memiliki kemampuan untuk memilih dari agama mana yang baik menurut 
dirinya atau tidak. Inilah perdebatan panjang manusia dalam nalarnya dan wahyu Tuhan yang dianggap sebagai pedoman namun tak jarang berbeda dengan fakta lapangan.

Dari pembahasan sederhana di atas setidaknya dapat diambil beberapa kesimpulan sebagai berikut:

Pertama, bahwa teks agama baik al-Quran, hadis maupun hasil ijtihad ulama tidaklah muncul tanpa ada interaksi dengan realitas yang ada. Karena hal itu pula teks-teks agama tersebut pun tidak akan berfungsi sama-sekali ketika tidak dilakukan interaksi dengan realitas yang ada, sehingga pendekatan objektif terhadap teks adalah suatu yang sulit dilakukan mengingat perbedaan realitas yang ada. Kedua, NU yang memiliki Lajnah Bahtsul Masail secara umum lebih cenderung mendasarkan teks agama bukan pada al-Quran dan hadis, namun kepada hasil ijtihad ulama mazhab. Hal ini berkonsekuensi pada proses membumikan teks agama yang dilakukan baik subjektif maupun objektif adalah dengan dasar ulama dan bukan al-Quran dan hadis.

Ketiga, sikap subjektif LBM NU dalam menyikapi teks agama dalam bentuk ijtihad ulama baik salaf maupun khalaf membuat NU lebih bisa mengakomodir tradisi yang berbeda antar daerah atau bahkan antar agama dengan memberikan berbagai pilihan dari berbagai mazhab yang ada. Keempat, sikap subjektifitas dalam beragama lebih sering mengacu pada hal yang memang tidak dijelaskan di dalam teks agama, termasuk ijtihad ulama. Karenanya, bersikap objektif terhadap teks agama yang jelas dan tegas seperti amalan ibadah dan keimanan adalah hal yang final dan tidak bisa digantungkan pada subjektifitas pembaca atau penafsir teks. Wallahu a'lam.

\section{Daftar Pustaka}

Abdul Mughits. Kritik Nalar Fiqih Pesantren. Jakarta: Kencana, 2008.

Abu Yasid. Nalar dan Wahyu: Interrelasi dalam Pembentukan Syari'at. Jakarta: Erlangga, 2007.

Abū Zaid, Naṣr Ḥāmid. Mafhūm al-Naṣṣ: Dirāsah fi 'Ulūm al-Qur'ān (Kairo: alHaiah al-Miṣriyah li al-Kitāb, 1993.

al-Baihaqi, Abū Bakar Aḥmad. Sunān al-Kubra. Mekah:Maktabah Dar al-Barf, tth.

Al-Baihaqi. Shu'ab al-İmān. Beirut: Dar al-Kutub al-Ilmi, tth.

al-Bukhari, Muhammad Ibn Ismail. Sahịh al-Bukhārí. Beirut: Dar Ibn Katsir, 1978. 
Depdikbud. Kamus Besar Bahasa Indonesia. Jakarta: Balai Pustaka, 1988.

Dhofier, Zamakhsyari. Tradisi Pesantren Tentang Pandangan Hidup Kyai. Jakarta: LP3ES, 1982.

Ibn Hanbal, Ạ̣mad. Musnad al-Imām Ahmmad Ibn Hanbal. Kairo: Mausu'ah Qurtubi, tth.

Ibn Hiibban, Muhammad. Saḥ̣̂̆ Ibn Hibbān. Beirut: Muassasah al-Risalah, 1993. Ibn Mājah, Muhammad Ibn Yazìd. Sunan Ibn Mājah. Beirut: Dar al-Fikr, tth.

Mahfuz, Mahsun dan Baedhowi. "Mencermati Perkembangan Pemikiran Hukum Islam di Indonesia; Studi Apresiatif atas Pemikiran KH. MA. Sahal Mahfudh tentang Fikih Sosial", Jurnal, edisi 7 vol. iv April 2008.

Masyhuri, Aziz. Hasil Muktamar dan Munas Ulama NU tahun 1926-1994. Surabaya: Dinamika Press, 1997.

Misrawi, Zuhairi. Hadratus Syaikh Hasyim Asy'ari; Moderasi, Keumatan, dan Kebangsaan. Jakarta: Kompas, 2010.

Nasih, Ahmad Munjih. 'Bahtsul Masail dan Problematikanya di Kalangan Masyarakat Muslim Tradisional”, Jurnal al-Qanun, Vol. 12, No. 1, 2009.

al-Nisaburi, Abū Abdullah al-Ḥakim. Mustadrak 'Alā Saḥiḥain. Beirut: Dar alKutub al-Ilmi, 1990.

PBNU. AD ART NU. Jakarta: PBNU, 2004.

PW LTN NU Jatim. Ahkamul Fuqaha; Solusi Problematika Hukum Islam, Keputusan Muktamar, Munas dan Konbes Nahdlatul Ulama (1926 2004). Surabaya: Khalista dan LTN NU, 2007.

Ridwan. "Mistisisme Simbolek Pada Tradisi Islam Jawa," Jurnal Ibda, STAIN Purwokerto, Vol. 6, No. 1, 2008.

Siddiq, Acmad. Khittah Nahdliyyah. Surabaya: Khalista, 2005.

al-Tirmidhi, Abū İsa Muhammad. Sunan al-Tirmidhi. Kairo: Dar al-Fikr, tth.

Weinstock, Daniel. "Beyond Objective dan Subjective: Assessing the Legitimacy of Religius Claims to Accomodation," The Ethics Forum, Vol. 6, No. 2, (2011).

Zahro, Ahmad. Lajnah Bahtsul Masail 1926-1999; Tradisi Intelektual NU. Yogjakarta: LKiS, 2004. 